\title{
THE PECULIARITIES OF FATIGUE PROCESS ZONE FORMATION OF STRUCTURAL MATERIALS
}

\author{
Roman CHEPIL ${ }^{1}$, Volodymyr VIRA ${ }^{2}$, Volodymyr KULYK ${ }^{2}$, \\ Yevhen KHARCHENKO ${ }^{2,3}$, Zoia DURIAGINA ${ }^{2,4}$ \\ ${ }^{1}$ Karpenko Physico-Mechanical Institute of the NAS of Ukraine \\ Naukova Str. 5, 79060 Lviv, Ukraine, romanchepil68@ gmail.com, \\ ${ }^{2}$ Lviv Polytechnic National University, S. Bandery Str. 12, 79013 Lviv, Ukraine, viravolodymyr@gmail.com, \\ kulykvolodymyrvolodymyrovych@gmail.com \\ ${ }^{3}$ University of Warmia and Mazury in Olsztyn, Faculty of Technical Science, \\ Oczapowskiego str. 11D, 10-736 Olsztyn, Poland kharchen@wp.pl \\ ${ }^{4}$ The John Paul II Katholic Uniwersity of Lublin, Faculty of Physical Chemistry and Physicochemical \\ Fundamentals of Environmental Engineering, Racławickie Al. 14, 20-950 Lublin, Poland, zduriagina@ukr.net

\section{Summary} \\ It is shown that with a cyclic loading in the vicinity of the stress concentrator within the static and cyclic \\ plastic zones, a specific volume of material is gradually formed - the fatigue process zone. Its size $d^{*}$ \\ determines the length of non-propagated cracks or safety defects in the material and can be a determining \\ factor in the diagnosis of material damage. For these materials, the size $d^{*}$ does not depend a lot on the type \\ and geometric characteristics of the stress concentrator. It can be determined by laboratory conditions. While \\ detecting the defects which are longer than $d^{*}$, it is decided to reduce the intervals between inspections of the \\ construction element, repair or replace it.
}

Keywords: fatigue, durability, fatigue process zone, crack initiation and growth, defects of materials

\section{OSOBLIWOŚCI TWORZENIA STREFY PROCESU ZMĘCZENIOWEGO W MATERIAŁACH KONSTRUKCYJNYCH}

\section{Streszczenie}

Pokazano, że cykliczne obciążenie w pobliżu koncentratora naprężeń w statycznych i cyklicznych strefach plastycznych stopniowo tworzy specyficzną objętość materiału - strefę procesu zmęczeniowego. Jej rozmiar $d^{*}$ określa długość nierosnoncych pęknięć lub innych bezpiecznych defektów i może być czynnikiem decydującym w diagnozie uszkodzeń materiału. Dla badanych materiałów rozmiar $d^{*}$ mało zależy od rodzaju i geometrycznych charakterystyk koncentratora naprężeń. Jego można wyznaczyć w warunkach laboratoryjnych. Po ujawnieniu defektów, dłóższych niż $d^{*}$, podejmuje się decyzja o skróceniu czasu między przeglądami elementa konstrukcji, jego remoncie lum zamianie.

Słowa kluczowe: zmęczenie; trwałość; strefa procesu zmęczeniowego; inicjacja i propagacja pęknięcia; defekty materiałowe

\section{INTRODUCTION}

Practically there are always certain defects in a material arising as a result of: incorrect technological process of manufacturing (metallurgical inclusions or cavities, faulty fusion); specific features of processing (scratches, burrs); influence of service conditions (corrosion pittings, microcracks) and other. Such defects become the place of stress concentration under loading and just at that place the accumulation of structural microdamages of the material and cracking occur that usually cause the total failure of the product. Therefore, a reliable diagnostics of the products damaging for assessing their residual lifetime, especially under cyclic loading, is a very important factor for the safe operation of industrial objects, technological equipment or structural elements. There are a number of methods for detecting damages or diagnosing the material state in oil and gas pipeline constructions [1, 2], railway transport [3-5] or aviation [6, 7]. It is clear that not all defects or micro-damages can cause the failure therefore it is necessary to know the minimum dimension of the damage that is of danger and that should be reliable detected.

The performed researches indicate that under cyclic loading the small size damages can occur in the material volume which do not influence or slightly influence the lifetime characteristics of the material. In particular, in the investigations by Frost and Dugdale [8] it was found that the endurance 
limit of the notched specimens is higher than that predicted by the linear formulation using data of smooth specimens testing. In this case when the notch radius $\rho<0.5 \mathrm{~mm}$, that is the stress concentration factor $K_{t}>6$, the endurance limit is constant (it doesn't depend on the notch radius). Still, when the endurance limit at the rack tip is lower the cracks initiate but they are nonpropagating, reaching the length of $200 \ldots 320$ microns.

Kitagawa and Takahashi proposed the diagram [9] that illustrated the dependence of stress range $\Delta \sigma_{N}$, necessary for the specimen failure, on length $a$ of the existing fatigue crack. If $a=0$ such stress range is equal to the endurance limit $\Delta \sigma_{R}$ and stresses do not change even when there is a crack shorter than a certain value $a_{0}$. In case we have the crack of length $a>a_{0}$, the crack length $a$ increment corresponds to the decrease of the stress range $\Delta \sigma_{N}$. The short crack critical length $a_{0}$ is constant for a given material and test conditions and for its calculation El Haddad proposed the empirical dependence $a_{0}=\frac{1}{\pi}\left(\frac{\Delta K_{t h}}{\Delta \sigma_{R}}\right)^{2}$, where $\Delta K_{t h}$ is fatigue threshold of the material. This value is called a structural parameter of the material but no physical substantiation is proposed $[10,11]$. It is shown for a number of materials that $a_{0}$ corresponds to the maximum size of non-propagating fatigue cracks [12] and its value does not depend on $K_{t}$, i.e. on the notch radius $\rho$, so this is a certain constant of the material.

A number of researchers have established [1315] that under testing of the notched specimens with the same notch depth $h=$ constant and nominal stress range $\Delta \sigma_{N}=$ constant, with the decrease of the notch radius $\rho$ the number of cycles $N_{i}$ to the macrocrack initiation decreases proportionally. However, if the radius becomes less than some value $\rho_{0}$, because of the material properties, the number of cycles to the macrocrack initiation remains constant.

Thus the mentioned parameters ( $a_{0}$ or $a_{0}$ ), that are structural parameters of the material and their size varies from ten microns to $1 \ldots 2 \mathrm{~mm}$, can be criteria of the safe crack or defect dimensions.

Within the frames of the unified model of fatigue fracture [16] it is proposed to consider as a structural parameter the fatigue process zone (FPZ) of size $d^{*}$, which unlike the above parameters, contains some physical meaning and it can detect local stress, deformation or energy in the vicinity of the concentrator. This is a maximum plastically deformed zone within the cyclic plastic zone localized in a narrow (of the depth to several tenth of millimeter) near-surface layer, what is caused by the effect of the properties of the body free surface [12].

Just here the primary damaging (defectiveness) of structure occurs and at the early stages of fatigue in the conditions of lower material yield resistance a local sliding proceeds easier and more intensive that alongside with the absence of closure effect, explains the lower fatigue threshold $\Delta K t h$ and the higher rate of microstructurally short cracks growth to compare with the long ones [17]. Since as a result of plastic deformation in the process zone the maximum stresses at the notch tip, calculated within the elasticity theory, relax to the values of local stresses and their maximum is reached at distance $d^{*}$ from the notch tip [17], it can be considered that the size of the process zone is a certain constant of the material under given test conditions (loading amplitude, temperature, environment).

The aim of the research is the investigation of the peculiarities of the fatigue process zone formation and the initial period of fatigue crack initiation at the notch tip.

\section{MATERIALS AND PROCEDURES}

Tests were carried out on the standard specimens of size $\mathrm{W}=25 \mathrm{~mm}$ and $40 \mathrm{~mm}$ with the rounding notch radii: $\rho=0.75 ; 1.5 ; 2.5 \mathrm{~mm}$, thus providing the variation of the stress concentration values at the notches. Specimens were prepared from the low-carbon high-ductility steel 08kp (yield strength $190 \mathrm{MPa}$; ultimate strength $270 \mathrm{MPa}$; elongation 48\%), aluminum alloys of types 2024-T3 (275 MPa; $425 \mathrm{MPa} ; 11 \%$ ) and 7075-T6 (485 MPa; $525 \mathrm{MPa} ; 12 \%$ ) in as-received state.

Fatigue tests were conducted on a servohydraulic machine BISS at constant loading amplitude with a frequency of $10 \ldots 15 \mathrm{~Hz}$ and stress ratio $R=P_{\min } / P_{\max }=0.1$ and 0.5 in laboratory air. Changes near the stress concentrator were recorded on the optical microscope with a 200-time magnification.

Dimensions of the fatigue process zone and the peculiarities of its formation were determined by the following methods:

1) the method of laser interferometry by the change of the specimen cross-section in the vicinity of the stress concentrator caused by plastic deformation, where the point with the maximum local deformation corresponds to size $d^{*}$ of the plastic zone i.e. the cross - section becomes minimum [18];

2) the optical method based on the analysis of the specimen deformed surface image in the stress concentrator vicinity, where a characteristic point that correlates with size $d^{*}$ of the process zone, is determined by the extremum of the function of distribution of deformation intensity of the surface along the notch axis [19].

\section{RESULTS AND DISCUSSION}

The $08 \mathrm{kp}$ steel specimens were cyclically loaded and the specimen surface profile change 
(thinning) in the notch vicinity (Fig. 1) was determined by the speckle-interferometry method using the phase shifting technologies of respective images processing [18].

After 1000 cycles the deformation maximum is at a distance of about 50 microns from the notch tip (Fig. 1b). Under further loading the value of deformation increases, what is proved by the increase of the interference curves, and the point of the deformation maximum displaces by a distance of 150 and 165 microns after 5000 and 10000 cycles, respectively (Fig. 1c, d). After 20000 cycles its size is 250 microns and a crack initiates at the notch tip with a length of about $250 \mu \mathrm{m}$ (Fig. 1e). At the crack tip the own process zone is formed and it again increases by $250 \mu \mathrm{m}$ (Fig. 1f).

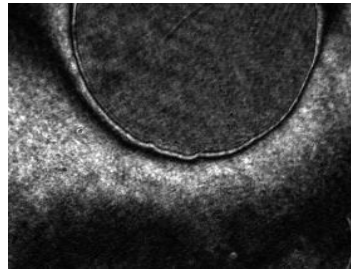

a

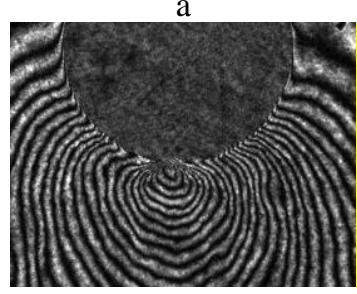

c

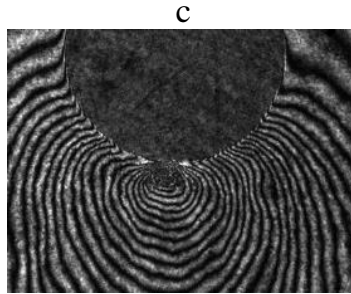

e

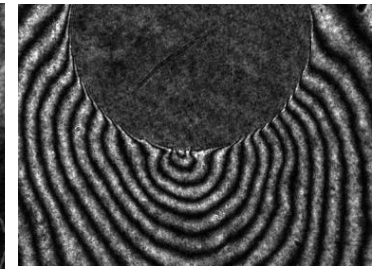

b

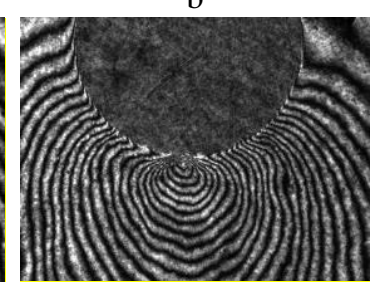

d

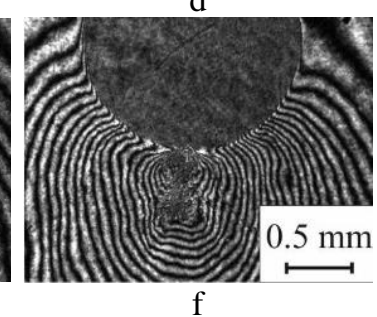

Fig. 1. Interference image of the deformation maximum in the stress concentrator vicinity in the initial state (a) and after1000 (b), 5000 (c), 10000

(d), 20000 (e), 25000 (f) loading cycles

So, the process zone, unlike the plastic zones, is formed not immediately but starting from the first cycle its size increases until reaches its maximum value (Fig. 1,2). Since the high-ductility $08 \mathrm{kp}$ steel shows a slight tendency to deformation strengthening, the size of the process zone $d^{*}$ for the number of cycles $N$, that is $30-40 \%$ of the macrocrack initiation period, somewhat stabilizes, while before crack initiation it somewhat increases (Fig. 2).

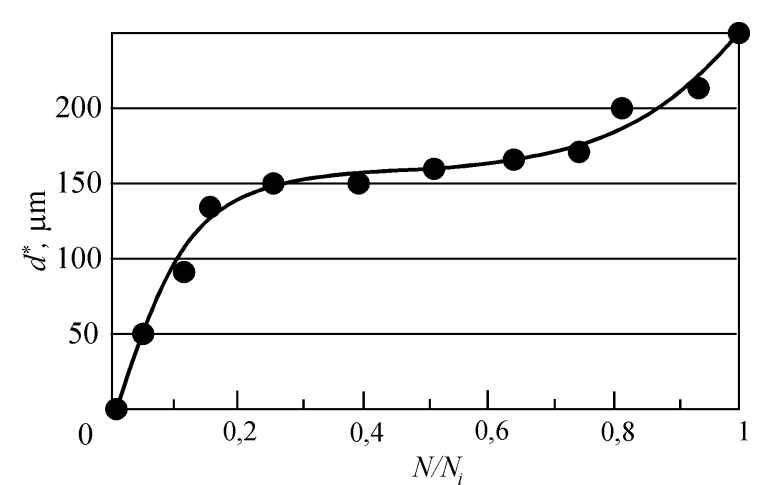

Fig. 2. Dependence of size $d^{*}$ on the relative number of cycles to macrocrack initiation in the $08 \mathrm{kp}$ alloy

For the investigated aluminum alloys the appearance on the horizontal region that corresponds to the established size $d^{*}$, is observed for a number of cycles $N$, what is $20-25 \%$ of period $N_{i}$ (Fig. 3). The difference between the $08 \mathrm{kp}$ steel and aluminum alloys can be related with the different rate of plasticity life exhaustion in the local zones of these materials.

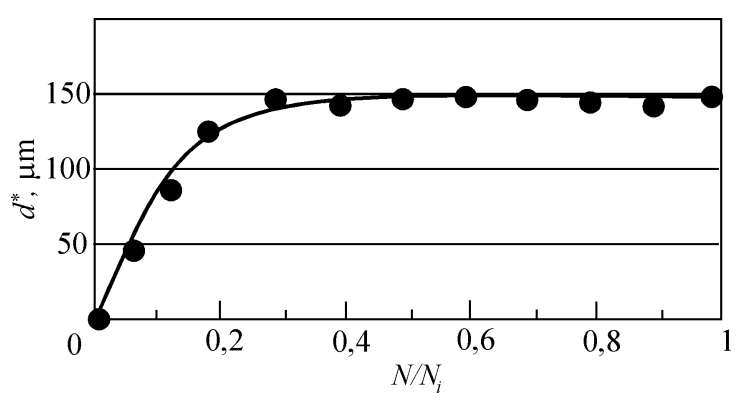

Fig. 3. Dependence of size $d^{*}$ on the relative number of cycles to macrocrack initiation in the 7075-T6 alloy

An interference map was investigated in the vicinity of a stress concentrator without a crack in the 7075-T6 aluminum alloy specimen (Fig. 4).

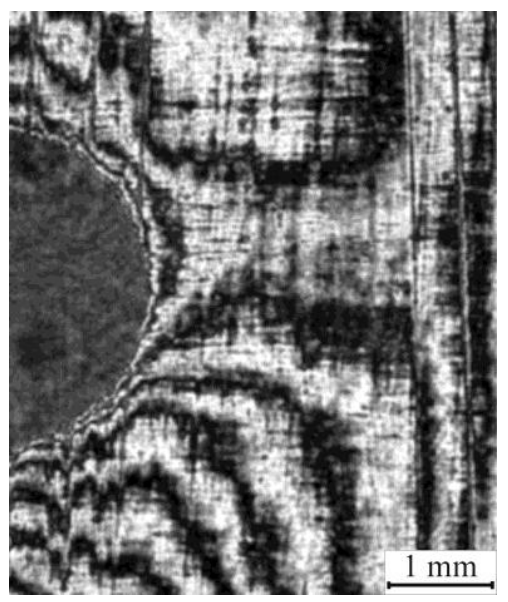

Fig. 4. Interference map in the vicinity of the stress concentrator without a crack in the 7075-T6 aluminum alloy specimen 
Very often under the action of cyclic loading of bodies with stress concentrators at the notch tip after incubation period, which makes up $N \approx(0.2 \ldots 0.4) N_{i}$, a system of microcracks, which size does not exceed $d^{*}$, is formed within the process zone (Fig. 5). In terms of $N=(0.6 \ldots 0.9) N_{i}$ the increment of one of the initial microcrack length is observed (Fig. 5), which at $N=N_{i}$ increases jump-like to size $a_{i} \geq d^{*}$ and becomes a macrocrack, while at its tip the own process zone starts to form (Fig. 6). Thus, according to the unified model of fatigue fracture there is a criterion of the initial macrocrack size $a_{i}=d^{*}$ [16], while the process zone is a physical barrier to the macrocrack initiation and the cracks, that did not go outside its borders, can be considered safe.

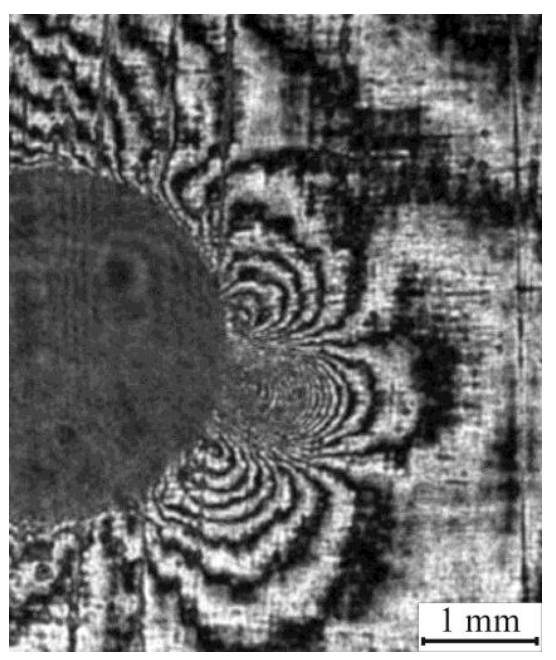

Fig. 5. Interference map in the vicinity of the stress concentrator with a system of microcracks in the aluminum alloy specimen

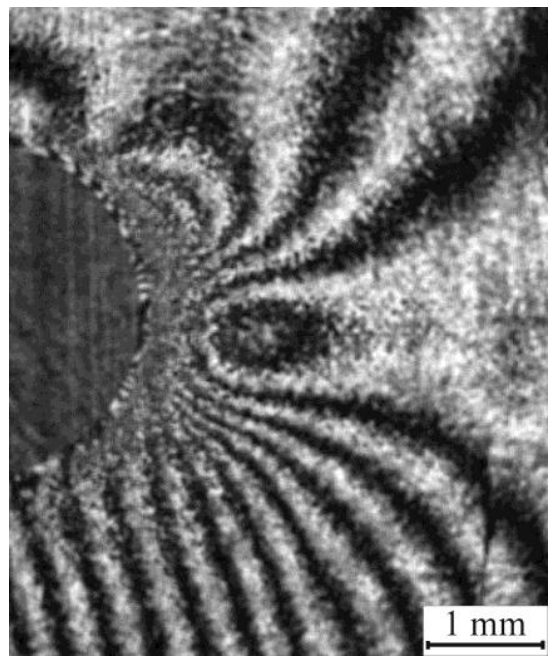

Fig. 6. Interference map in the vicinity of the stress concentrator at the moment of a macrocrack formation in the 7075-T6 aluminum alloy specimen

Visual observation showed that after a certain number of loading cycles the traces of plastic deformation appear on the plated surface of the 7075-T6 aluminum alloy specimen at the notch (Fig. 7-8 zone A), the intensity of which gradually increases. This zone propagates by some distance that determines size $d^{*}$ of the process zone independent of the notch radius $\rho$. The macrocrack within the process zone differs visually from the macrocrack outside it (Fig. 7-8, zones A and B). A part of the macrocrack, which is located in the zone of available plastic deformations due to the notch effect, is much less (Fig. 5-6, zone A) than a part of the macrocrack after formation of the visual own plastic zone near its tip (Fig. 7-8, zone B). Similar phenomenon takes place when the macrocrack propagates after cyclic overloading: within the process zone borders after overloading a crack is thin and propagates after leaving this zone. Thus, the moment of macrocrack initiation can be determined by visual signs. In this case, as our experience shows, the visual values of the initial macrocracks practically coincide with the size of the fatigue process zone. So, when the crack length $a>d^{*}$, it becomes a macrocrack with its own plastic zone for which the self-model conditions typical of macrocracks are satisfied.

Our investigations have demonstrated that parameter $d^{*}$, i.e. the size of the process zone, practically does not depend on the notch radius $\rho$ at least in a wide range of the interval values $\rho$ it slightly depends on it (Table 1) [16, 17].

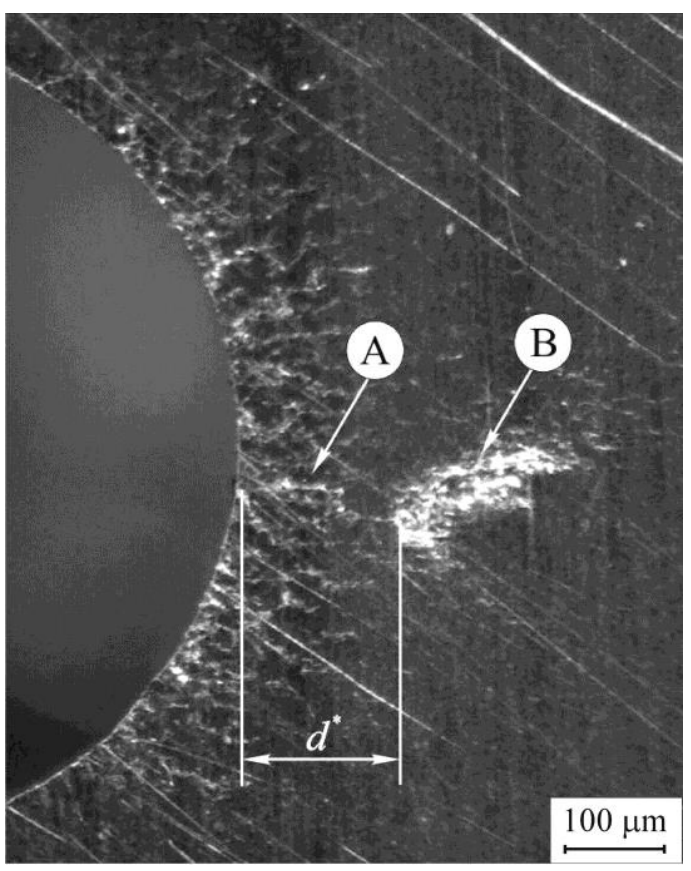

Fig. 7. Surface in the vicinity of the stress concentrator at the stage of the initial macrocrack formation (zone $\mathrm{A}$ ) and at the stage of the macrocrack growth (zone B) at $R=0.1, \rho=0.75 \mathrm{~mm}$

One of the basic factors that have an influence on the process zone size is stress ratio. Experimental investigations carried out by different above presented procedures demonstrate that with incre- 
ase of $R$ from 0.1 to 0.5 parameter $d^{*}$ increases from 150 to 180 microns for the aluminum alloy of type 7075-T6 and from 120 to 160 microns for the aluminum alloy of type 2024-T3.

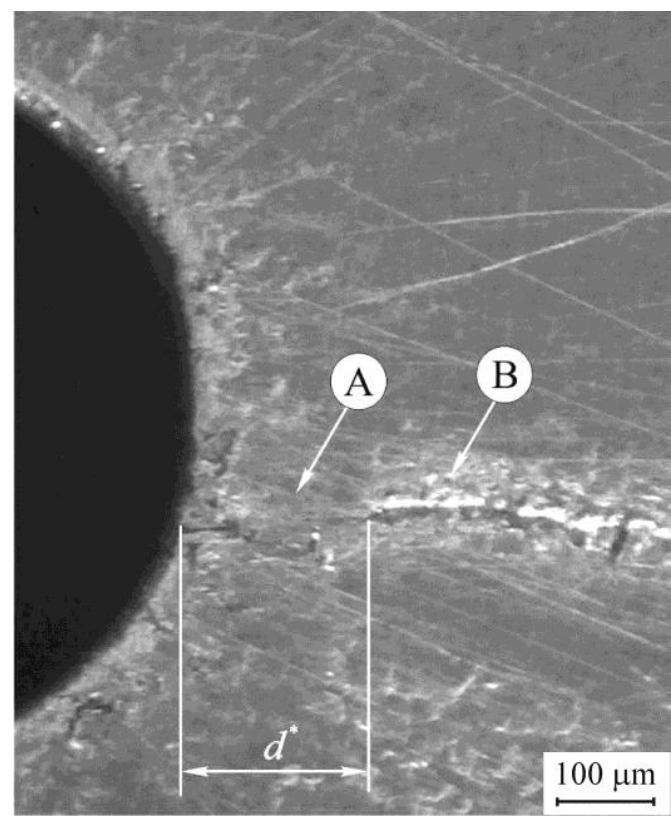

Fig. 8. Surface in the vicinity of the stress concentrator at the stage of the initial macrocrack formation (zone A) and at the stage of the macrocrack growth (zone $\mathrm{B}$ ) at $R=0.5, \rho=0.75 \mathrm{~mm}$

Table 1. Size $d^{*}$ of the fatigue process zone in the specimens with a stress concentrator for different rounding radius of its tip.

\begin{tabular}{|c|c|c|c|}
\hline \multirow{2}{*}{ Material } & \multicolumn{3}{|c|}{$d^{*}, \mu \mathrm{m}$} \\
\cline { 2 - 4 } & $\rho=0.75 \mathrm{~mm}$ & $\rho=1.5 \mathrm{~mm}$ & $\rho=2.5 \mathrm{~mm}$ \\
\hline $\begin{array}{c}\text { al. alloy } \\
\text { 2024-T3 }\end{array}$ & 140 & 130 & 130 \\
\hline $\begin{array}{c}\text { al. alloy } \\
\text { 7075-T6 }\end{array}$ & 150 & 160 & 150 \\
\hline $\begin{array}{c}\text { steel } \\
\text { 08kp }\end{array}$ & 270 & 280 & 250 \\
\hline
\end{tabular}

\section{CONCLUSIONS}

In the conditions of cyclic loading in the stress concentrator vicinity the fatigue process zone is gradually formed, which size $\mathrm{d}^{*}$ is the determining parameter of the fatigue processes of the structural materials. The steps and peculiarities of its formation have been experimentally investigated. In particular, it has been shown that the parameter $\mathrm{d}^{*}$ does not depend on the radius of the notch, increases with increasing the asymmetry of the load cycle, and also determines the value of nonpropagating (safe) cracks or defects in the structural materials and can be a criterial parameter when diagnosing the material defectiveness or damaging.

\section{REFERENCES}

1. Tsyrul'nyk OT, Nykyforchyn HM, Petryna DY, Hredil' MI, Dz'oba IM. Hydrogen degradation of steels in gas mains after long periods of operation. Materials Science. 2007; 43(5): 708-717. https://doi.org/10.1007/s11003-008-9010-5

2. Krechkovs'ka HV, Mytsyk AB, Student OZ, Nykyforchyn HM. Diagnostic indications of the inservice degradation of the pressure regulator of a gastransportation system. Materials Science. 2016; 52(2): 233-239. https://doi.org/10.1007/s11003-0169949-6

3. Ostash OP, Andreiko IM, Kulyk VV, Uzlov IH, Babachenko OI. Fatigue durability of steels of railroad wheels. Materials Science. 2007; 43(3): 403414. https://doi.org/10.1007/s11003-007-0046-8

4. Markashova LI, Poznyakov VD, Gaivoronskii AA, Berdnikova EN, Alekseenko TA. Estimation of the strength and crack resistance of the metal of railway wheels after long-term operation. Materials Science. 2012; 47(6): 799-806.

https://doi.org/10.1007/s11003-012-9458-1

5. Ostash OP, Andreiko IM, Kulyk VV, Vavrukh VI. Influence of braking on the microstructure and mechanical behavior of railroad wheel steels. Materials Science. 2013; 48(5): 569-574. https://doi.org/10.1007/s11003-013-9539-9

6. Nesterenko BG, Nesterenko GI. Fatigue and damage tolerance of aging airplane structures. Advanced Materials Research. 2014; 891-892: 16691674. https://doi.org/10.4028/www.scientific.net/AM R.891-892.1669

7. Dziendzikowski M, Dragan K, Kurnyta A, Klysz S, Leski A. Health monitoring of the aircraft structure during a full scale fatigue test with use of an active piezoelectric sensor network. Solid State Phenomena. 2015; 220-221: 328-332.

https://doi.org/10.4028/www.scientific.net/SSP.220221.328

8. Frost NE, Dugdale DS. Fatigue test of notched mild steel plates with measurements of fatigue cracks. Journal of the Mechanics and Physics of Solids. 1957; 5(3): 182-192. https://doi.org/10.1016/00225096(57)90004-2

9. Kitagawa H, Takahashi S. Applicability of fracture mechanics to very small cracks or the crack in the early stage. 2-nd Int. Conf. On Mechanical Behaviour of Materials, ICM2, ASM Metal Park, Ohio. 1976: 627-631.

10. El Haddad MH, Topper TH, Smith KN. Prediction of non-propagating cracks. Engineering Fracture Mechanics. 1979; 11(3): 573-584. https://doi.org/10.1016/0013-7944(79)90081-X

11. El Haddad MH, Dowling NF, Topper TH, Smith KN. J-integral applications for short fatigue cracks at notches. International Journal of Fracture. 1980 16(1): 15-30. https://doi.org/10.1007/BF00042383

12. Abdel-Raouf H., Topper T. H., Plumtree A. A model for the fatigue limit and short crack behaviour related to surface strain redistribution. Fatigue and Fracture of Engineering Materials and Structures 1992, 15(9): 895-909.

https://doi.org/10.1111/j.1460-2695.1992. tb00065.x

13. Irvin GR. Fracture. Handbuch der Physic. 1958, 6: 551-590. 
14. Tobler RI, Shu OS. Fatigue crack initiation from notches in austenitic stainless steel. Cryogenic. 1986, 26(7): 396-401. $\quad$ https://doi.org/10.1016/00112275(86)90083-4

15. Devaux JC, D'escantha J, Rabbe P, Pellissier-Tanon A. A criterion for analysing fatigue crack initiation geometrical singularities. Trans. $5^{\text {th }}$ Int. Conf. Struct. Mech. React. Technol., Berlin, 1979. G8 (1): 1-8.

16. Ostash OP, Panasyuk VV, Kostyk EM. A phenomenological model of fatigue macrocrack initiation near stress concentrators. Fatigue and Fracture of Engineering Materials and Structures. 1999, 22(2): 161-172. https://doi.org/10.1046/j.14602695.1999.00098.x

17. Ostash OP, Panasyuk VV. Fatigue process zone at notches. International Journal of Fatigue. 2001, 23(7): 627-636. http://doi.org/10.1016/S0142-1123(01)00004-4

18. Ostash OP, Muravs'kyi LI, Voronyak TI, Kmet' AB, Andreiko IM, Vira VV. Determination of the size of the fatigue prefracture zone by the method of phaseshifting interferometry. Materials Science. 2011; 46(6): 781-788. https://doi.org/10.1007/s11003-0119353-1

19. Ostash OP, Chepil RV, Andreiko IM, Vira VV, Prokopets VI. Patent of Ukraine № 69067. Method of determining the size of the fatigue process zone. Published: 25.04.2012, Bulletin 8.

Received 2018-05-26

Accepted 208-09-03

Available online 2018-09-04

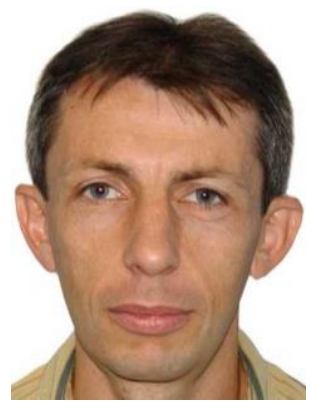

Roman CHEPIL, Ph.D. works at Karpenko PhysicoMechanical Institute of National Academy of Sciences of Ukraine (Department of Microstructural fracture mechanics of materials). The branch of scientific interests is the fatigue mechanics of material destruction, in particular the establishment of parameters of local destruction and determination of durability of structures under the action of cyclic loading. The author of about 60 scientific works.

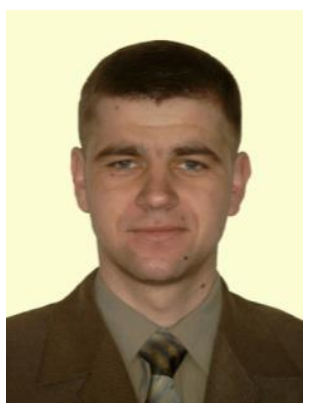

Volodymyr VIRA, Ph.D. works at Department of Strength of Materials and Structural Mechanics of Lviv Polytechnic National University, Ukraine. Prior workplace at Karpenko Physico-Mechanical Institute of National Academy of Sciences of Ukraine, Lviv. V. Vira has more than 15 years' experience of the full time scientific studies in fatigue fracture mechanics of structural materials. $\mathrm{He}$ is evaluating the fatigue durability of notched bodies on crack initiation and propagation stages. The author of about 50 scientific papers, including 2 patents.

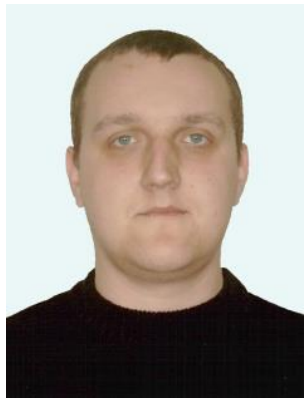

Volodymyr KULYK, Ph.D. works at Department of Applied Materials Science and Materials Engineering of Lviv Polytechnic National University, Ukraine. Prior workplace at Karpenko Physico-Mechanical Institute of National Academy of Sciences of Ukraine, Lviv, Ukraine. In scientific work, research works are carried out to evaluate the serviceability of materials under the influence of operational factors. The author of about 110 publications, including 1 book and 2 patents.

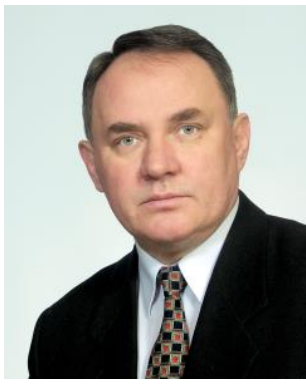

Yevhen KHARCHENKO, Prof., dr hab. eng. - works at Department of Mechanics and Bases of Designing in University of Warmia and Mazury in Olsztyn, Poland and Department of Strength of Materials, and Structural Mechanics of Lviv Polytechnic National University Ukraine. In scientific work conducts research in the theory of linear and nonlinear vibrations of discretecontinuum mechanical systems. Engaged in problems of dynamics, strength and technical diagnostics of machines and engineering structures. The author of about 300 scientific papers, including 2 monographs and 30 patents.

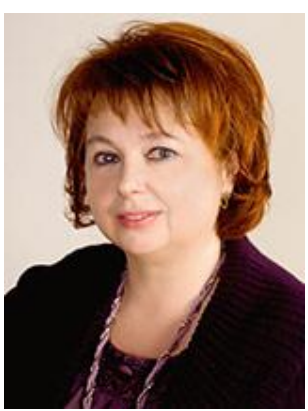

Zoia DURIAGINA, Prof., $\mathrm{dr}$ tech. sciences and dr hab. eng. - works at Department of Applied Materials Science and Materials Engineering of Lviv Polytechnic National University, Ukraine and Department of Physical Chemistry and Physico-Chemical Fundamentals of Environmental Engineering of The John Paul II Catholic University of Lublin, Poland. In scientific work, studies are conducted between the nano- and microstructure of the material and its physico-chemical properties, which is the main problem in the development of new materials with special properties. The author of about 235 publications, including 10 books and 16 patents. 